\section{NATIONALIZATION OF MINERAL RIGHTS}

$\mathrm{I}^{\mathrm{N}}$ July 1944 the Institution of Mining and Metallurgy discussed a paper by Prof. W. R. Jones in which he advocated the acquisition by the State of mineral rights. On that occasion he restricted his proposals to minerals as contrasted with rocks and so did not include roadstones, building stones, limestone, brick clays, sands and gravels. In a later paper submitted for discussion in September of this year, he has extended his advocacy of nationalization to this larger group.

It is noted that Great Britain is almost unique in the British Empire in that the mineral rights are not vested in the Grown or in the Government. Two important steps have already been taken towards nationalization. Under the Petroleum Production Act of 1934 the ownership of petroleum occurring in Britain is vested in the Crown; under the Coal Act of 1938 the State purchased the mineral rights in coal by compensating the royalty owners on a basis of a fifteen-year purchase of royalties. In addition, it has long been accepted that the royal metals, gold and silver, and also any minerals lying under tidal or territorial waters, belong to the Crown. Prof. Jones now advocates the acquisition of all mineral rights on the same basis as that used in the case of coal. $\mathrm{He}$ is careful to point out that State acquisition of mineral rights has nothing to do with nationalization of mines.

In the earlier paper Prof. Jones deals mainly with lead-zine, tin and china clay. In the case of lead-zinc, it is urged that low-grade ores remain to be worked, which it is in the national interest to use but which cannot be done except under a large co-ordinated schems involving drainage and centralized smelting. In the case of tin he deduces from the now well-known phenomena that copper lodes give place in depth to tin lodes with a relatively barren zone separating the two, that rich tin deposits may underly many old abandoned copper mines in the south-west of England; but that the problem is a national one which could be tackled only after the acquisition of the mineral rights.

In the second paper Prof. Jones mentions, though he does not perhaps stress sufficiently, the profligate waste of land now resulting annually from the working of gravel, sand, iron ore and other surface minerals.

The most startling feature of the papers is the relatively small cost involved. The figure for all base-metal minerals is only $£ 421,000$; for iron ore less than $\$ 4,000,000$, and for all the minerals of Britain less than $£ 22,000,000$.

If the policy is regarded as right for coal and oil, it seems difficult to resist the conclusion that it is right for other minerals, but it would seem that Prof. Jones has only considered part of the problem. The State acquisition of petroleum rights was made before, and in intelligent anticipation of, the discovery of petroleum in quantity; and no land owner could truthfully feel himself unjustly deprived of his rightful possessions since he did not know such existed. Prof. Jones's proposals deal with acquisition by the State of other mineral rights by payment to owners in known mineral-bearing areas. It is here that a link with the general trend of policy regarding land planning suggests itself. If the State were to acquire all development rights in undeveloped land (that is, on land which is at present agricultural or afforested or open) and thus eifectively control surface development, these rights would obviously include any development of minerals. Quite clearly this would solve the pressing problems arising from surface working of coal, iron ore, gravel, sand, limestone and clay, where so much valuable agricultural land is being wasted through absence of adequate provision for restoration. It would permit the control, in the national interests, of the location of mineral workings of all types and open the way for the much-needed balanced planning of the use of the land of Britain.

L. Dudlex Stamp.

\section{THE ROYAL STATISTICAL SOCIETY INDUSTRIAL AND AGRICULTURAL RESEARCH
SECTION}

$\mathrm{T}$ HE Council of the Royal Statistical Society has decided that the Industrial and Agricultural Research Section, the activities of which were suspended at the outbreak of war, shall be reconstituted in the form of two separate sections-a Research Section and an Industrial Application Section.

From its inception in 1933, the Industrial and Agricultural Research Section met the needs of the growing number of workers interested in applying statistical methods to industry and agriculture. It held regular meetings at which papers were read and discussed, and published the Supplement to the Journal of the Royal Statistical Society, which not only contained these papers with reports of the discussions, but also provided a medium for the publication of new developments in the field of applied statistics.

During the War, statistical methods were applied on a greatly increased scale; in particular the need became apparent in industry for a common meeting ground where the experiences and difficulties arising in the practical application of statistical techniques could be discussed. On the initiative of Dr. B. P. Dudding, an informal Industrial Applications Group was formed in London to fulfil this need, and it was clear from the success attending the activities of the Group that there existed a considerable body of people who, though not necessarily professional statisticians or scientific workers, were very much interested in the practical aspects of the application of these new techniques to industry.

The Council of the Royal Statistical Society feels that the two distinct needs which are now evident will be catered for more adequately by the reorganization which has been effected. The Research Section will be concerned with the theory of statistics and statistical methods and with the development of new applications, while the Industrial Applications Section covers the practical application of statistical technique to industrial research, development, and manufacture, including inspection.

The Research Section, which will meet in London, proposes to hold four meetings during the coming session. Papers read at these meetings will be published in the Supplement to the Society's Journal, together with reports of the discussions. Details of the meetings will be announced in Nature and other appropriate journals. Visitors who are not members of the Section will be welcome.

The Industrial Applications Section is organized in local groups. In London, Birmingham and Sheffield, 
groups are already in existence, and the formation of groups at a number of other centres is under consideration. Discussions at group meetings will not in general be published, but should the local group committee consider certain papers to be of sufficient importance, their publication and method of distribution will be considered. Meetings of the groups will be announced in the appropriate journals.

The Supplement to the Society's Journal is edited by the Committee of the Research Section under direction from the Council of the Society. It is hoped that, in addition to publishing papers read before the Research Section, it will become a medium for the publication of research work on topics of general interest to statisticians. Such papers need not necessarily be theoretical or mathematical but should expound or illustrate some new development in statistical methodology. At present, papers of this nature are often published in journals devoted to special branches of science and not always readily accessible to workers in other fields.

Membership of either or both Sections is open to fellows of the Society free of charge and to nonfellows who are approved by the appropriate Section Committee, on payment of an annual subscription of ten shillings (for each Section). The Supplement to the Journal will be published twice yearly. It will be available to fellows of the Society free of charge and to members of the Sections at reduced rates. Further information may be obtained from the Assistant Secretary, Royal Statistical Society, 4 Portugal Street, London, W.C.2.

\section{RESEARCH WORK AT THE MILLPORT MARINE LABORATORY*}

$\mathrm{T}$

HIS series of annual reports recently issued by the Scottish Marine Biological Association, covering as they do the war years $1939-44$, are of great interest. Not only has the work been well maintained, but also the new wing, representing a considerable extension of the laboratory buildings, opened in June 1939, has been in general use. The staff, in spite of several members being absent on war service, has been extremely active and, in addition, workers from out. side have added to the programme in various ways. This has been chiefly on the economic side, but ecological and faunistic work has still continued.

Dr. Orr's analysis of the various marine organisms with regard to their nutritive value, based on two hundred different species, including molluscs, crustaceans, fishes, cclenterates, echinoderms and worms, shows that molluses, crustaceans, fishes and worms are of high food value, echinoderms and cœlenterates low. The results have been tabulated. His more recent work has been chiefly an investigation of seaweeds with special attention to those likely to provide substitutes for Japanese agar. This research, later in collaboration with Dr. S. Marshall and throughout in close touch with representatives of the Ministries of Supply and Health, resulted in a satisfactory agar substitute being found in the red alga, Gigartina stellatus, which is now being used on a commercial scale. A survey of algæ is also being carried out.

Dr. S. Marshall, who in the early part of the period was occupied with the life-histories of certain cope-

* Annual Reports of the Scottish Marine Biological Association (1938-39, 39-40, 40-41, 41-42, 42-43, 43-44). (185 St. Vincent Street, Glasgow.) pods, besides this agar work, is, together with Dr. Orr and Dr. F. Gross and J. E. G. Raymont, of the University of Edinburgh, taking part in an interesting experiment in Loch Sween and its small arm Loch Craiglin, by fertilizing the water by the addition of nutrient salts and investigating the effect on the growth of the phyto- and zoo-plankton, and of the fish introduced. An account of this was given in Nature ${ }^{1}$. Latest reports show that the added nutrients were rapidly absorbed and an increase in the size of the fish was in many cases large.

The question as to the value of marine plankton as food for land animals was raised by Sir John Graham Kerr in 1941, and Prof. A. C. Hardy of Aberdeen, with the approval of the Agricultural Research Council, took the matter up and devised experiments in cooperation with the Millport Station, primarily to see if plankton could be obtained in sufficient quantities to be used to form an addition to protein meal for animal stock and poultry. Good samples of Calanus meal were prepared, but the results during the three years did not yield the hoped-for practical results, although Prof. Hardy regards it as a speculative investigation which was well worth trying as a possible additional source of protein in war-time.

In 1941, Dr. J. E. Harris, working under the Marine Corrosion Sub-Committee of the Iron and Steel Institute, began his researches at Millport on problems connected with the marine fouling of metals. This work has increased considerably and several assistants are now working at the various subjects, including the colonization of the experimental rafts with plant and animal growth. Much valuable information has been obtained in connexion with these researches, the technical side of which will be published in the reports of the Marine Corrosion Sub-Committee. On the biological side, among other points of interest, are K. A. Pyefinch's work on the barnacle larvæ and Dr. M. Mare's on the succession of algæ and on the part played by the bacterial slimes in the development of fouling growth.

Experiments on prawn trawling and on the production of seaweed meal were also made, and besides the work of direct economic importance ecological studies have continued, especially in Kames Bay, by Dr. A. C. Stephen and others, including the molluscan and crustacean fauna, the microfauna of the intertidal sands, and insect larvæ of the shore.

The food of the shag was investigated by A. J. Hadow and W. H. R. Lumby, who show close agreement with Steven's ${ }^{2}$ observations, the bird being of little economic importance.

1 Nature, 153, 483 (1944).

'J. Mar. Biol. Assoc., 19, 277.

\section{INDIAN PLYWOOD FOR TEA CHESTS}

$\mathrm{T}$ HE long stretch of country situated at the foot of the eastern Himalaya is occupied by a succession of tea gardens which extend up into the outer hills to some $5,000 \mathrm{ft}$. or so elevation on the west. Since the introduction of the growth of tea into the region, the necessary tea box or chest for packing and exporting the tea has been something of a problem with a varied history. In the supply of those gardens situated in Assam, saw mills were erected in Assam many years ago, but most of the chests required came 